\title{
STUDI KASUS: OBSERVASI PENERAPAN METODE BEDSIDE PADA PROSES BEDSIDE TEACHING DI BANGSAL PENYAKIT DALAM RUMAH SAKIT SARDJITO YOGYAKARTA
}

\author{
Rhendy Wijayanto \\ Fakultas Kedokteran Universitas Pelita Harapan \\ Email: rhendyw@gmail.com
}

\begin{abstract}
Bedside teaching is an excellent opportunitiy for spontaneuous interaction between student, clinical supervisor, and patient. In bedside teaching sessions there are possibilities for appropriate and inappropriate encounter. Clinical supervisor observes and gives feedback in order to create a useful bedside teaching session for student. Bedside teaching session observed in Internal Ward of Sardjito Hospitol has applied Briefing, Expectation, Demonstration, Specific feedback, Inclusion of microskill teaching, Debriefing and Education accordingly. Student has obtained optimal learning opportunity from the event.
\end{abstract}

Keywords: Bedside teaching, clinical, feedback

\begin{abstract}
ABSTRAK
Bedside teaching adalah suatu kondisi yang baik untuk interaksi yang spontan antara mahasiswa, pembimbing klinik, dan pasien. Dalam sesi Bedside teaching terdapat kemungkinan terjadi prosedur yang sesuai ataupun yang kurang sesuai. Seseorang pembimbing klinik berperan untuk mengamati dan memberi umpan balik sehingga dapat menjadi sesi bedside teaching yang berguna bagi mahasiswa. Pelaksanaan Bedside teaching di Bangsal Penyakit Dalam RS Sardjito menerapkan tahapan Briefing, Ekspektasi, Demonstrasi, Umpan balik spesifik, Penerapan pengajaran microskill, Debriefing, dan Edukasi telah diterapkan dengan baik. Mahasiswa memperoleh manfaat yang optimal dari proses tersebut.
\end{abstract}

Kata kunci: Bedside teaching, klinik, umpan balik

\section{Pendahuluan}

Bedside teaching adalah semua kegiatan pembelajaran yang melibatkan pasien dalam prosesnya, tanpa mempertimbangkan setting apakah setting poliklinik, ruang perawatan, ataupun diadakan di dalam kelas ${ }^{1}$. Sementara dari segi pembelajaran, pendidikan klinik adalah suatu proses belajar mengajar yang berfokus pada mahasiswa ${ }^{1}$. Kegiatan ini merupakan penerjemahan dari teori ke pengetahuan dan keterampilan klinis, yang dipadu dengan domain afektif. Manfaat bedside teaching sangat besar karena mahasiswa yang tidak mengalami proses bedside teaching, akan kehilangan 
kesempatan untuk memperoleh pengetahuan dari pembimbing klinik dan dari pasien ${ }^{2}$. Peningkatan teknologi yang berbasis simulasi dan media ajar interaktif haruslah dicermati dan tidak dapat mengganti peran bedside teaching. Melalui interaksi antara pembimbing klinik dan mahasiswa dalam konteks workplace-based, mahasiswa dapat diberikan penilaian, umpan balik, serta refleksi yang sesuai dengan tujuan pembelajaran yang berbasis kompetensi Kompis dan Russi $^{4}$ menemukan bahwa simulasi dapat memunculkan suara pada pemeriksaan paru yang lebih jelas. Hal ini tidak sepenuhnya baik bagi pembelajaran karena di klinik mahasiswa akan mengalami kesulitan karena di pasien mungkin kelainan yang ditemui tidaklah sejelas itu.

\section{Pembahasan}

Proses pembelajaran mahasiswa saat menjalani kepaniteraan klinik dapat dikategorikan sebagai work based learning. Work based learning didefinisikan sebagai penghubungan anatara pembelajaran dengan peran saat bekerja ${ }^{5}$. Dalam pendidikan kedokteran maka hal ini menghubungkan belajar mahasiswa dengan perannya kelak sebagai dokter. Pembelajaran bedside teaching adalah tehnik yang terbaik untuk mempengaruhi mahasiswa dimana dapat diciptakan proses belajar aktif dalam konteks klinis yang otentik sementara menampilkan role model personal dan professional ${ }^{6}$.
Dari hasil observasi Bedside teaching yang dilakukan di Bangsal IImu Penyakit Dalam RS Sardjito didapati bahwa proses tersebut adalah proses yang membangun. Kunci penting untuk membuat suatu bedside teaching menarik adalah membuat proses tersebut student centered dan bukan menjadikan proses tersebut ajang bagi pembimbing utuk memamerkan keterampilan dan keahliannya, karena hal tersebut akan membosankan dan meningkatkan kadar stress pada mahasiswa ${ }^{7}$. Pada proses bedside teaching orientasi adalah hal penting. Mahasiswa diberi kesempatan untuk merumuskan apa yang ingin dipelajari. Data tersebut kemudian dibandingkan dengan apa yang ekspektansi pembimbing ${ }^{6 .} \quad$ Tujuan belajar ini bersifat dinamis dan dapat dimodifikasi selama proses berangsung.

Banyak topik dapat diajarkan lewat bedside teaching diantaranya kemampuan anamnesis, pemeriksaan fisik, etika klinis, humanism, professionalism, kemampuan komunikasi, dan memberikan contoh Role model $^{7}$. Namun jika proses pembeljaran di bedisde teaching ini tidak disupervisi, maka manfaat dari bedside teaching yaitu berupa memberikan feedback terhadap performa yang benar dan salah tidak tercapai. Hal ini dapat terjadi jika para pembimbing, sebelum memulai membimbing suatu rotasi mahasiswa tidak diberi briefing yang memadai mengenai kurikulum, apa yang harus diajarkan, dan bagaimana mengajar mahasiswa. Dengan semakin terlalu berlebihnya beban akademik, semakin 
tingginya tingkat perputaran pasien, dan ketergantungan akan tehnologi membuat proses pembelajaran dalam bedside teaching tidak berlangsug secara efektif ${ }^{7}$. Dalam pelaksanaan sering didapati tujuan yang tidak jelas. Hal ini membawa instruktur untuk memberikan pengetahuan yang tidak sesuai untuk tahap mahasiswa yang bersangkutan ${ }^{8}$.

Gordon $^{6}$ mengemukan beberapa pertanyaan reflektif kepada pembimbing klinik sebagai bagian dari persiapan pembimbingan. Pembimbing harus mengetahui apa tujuan utama dari proses pembimbingan tersebut. Pembimbing juga harus menyadari mengapa proses ini menjadi bagian dari proses pembelajaran. Pembimbing klinik juga harus mampu mengidentifikasikan kebutuhan mahasiswa, dan bagaimana nantinya mahasiswa membagikan pengalaman belajarnya kepada teman-temannya.

Persiapan adalah elemen kunci yang penting untuk menciptakan suatu bedside teaching yang efektif dan meningkatkan kenyamanan pembimbing klinik dalam melaksanakan tugas. Bagi pembimbing klinik, khususnya yang baru akan memulai suatu sesi bedisde teaching haruslah melakukan serangkaian persiapan. Pengenalan akan kurikulum klinik yang akan diajarkan penting diidentifikasikan. Sejauh mana mahaiswa telah menguasai materimateri klinis yang telah diberikan sebelumnya akan membantu pembimbing klinis meningkatkan kefektifan proses. Adalah hal penting untuk mehami bahwa untuk mengajarkan sesuatu, seseorang perlu terus belajar. Karena itu penting bagi pembimbing klinis mempersiapkan diri dengan mempelajari dan meningkatkan kualitas pemeriksaan fisik dan anamnesisnya sendiri sebelum mengajarkan ke mahasiswa. Belajar dapat dilakukan dengan melakukan diskusi dengan pengajar senior, maupun memperoleh bahan ajar dari multimedia. Seluruh kegiatan ini akan semakin baik dan tersturktur jika tertdapat sebuah training dari fakultas kepada para pembimbing klinik

Orientasi bagi mahasiswa adalah hal yang sangat penting. Pada sesi bedside teaching yang diamati, dalam konteks assessment, pembimbing klinis telah melakukan orientasi yang cukup baik. Sebelum memulai dan bertemu dengan pasien, pembimbing klinik menjelaskan tujuan dari bedside teaching. Karena sesi yang diamati adalah sesi penilaian; maka pembimbing memberikan kesempatan kepada mahasiswa untuk bertanya tentang hal-hal yang belum jelas dari kasus yang dihadapi. Sebelumnya pembimbing juga menekankan point apa yang akan dinilai pada sesi tersebut. Karena yang akan dinilai adalah sebuah sesi follow up, maka pembimbing menjelaskan secara singkat dan jleas kepada mahasiswa tentang diagnosis pasien yang akan dihadapi. Hal ini menurut pengamat sangatlah penting. Adanya petunjuk yang jelas ini akan membantu mahasiswa berorientasi dan mengefisienkan waktu kontaknya dengan pasien yang trelatif singkat sehingga dapat mencapai objective 
yang akan dinilai. Dalam bedside teaching yang melibatkan banyak mahasiswa, maka harus dijelaskan tentang peran masingmasing dan urutan pelaksanaan ketika berkontak dengan pasien. Adanya kejelasan tugas ini akan lebih membantu mahasiswa lebih tertarik pada proses tersebut. Dalam konteks ujian yang diamati, terdapat dua mahasiswa yang akan diuji. Urutan ujian yang jelas dan terpisah satu sama lain menbuat mahasiswa lebih siap dan percaya diri.

Pada awal pertemuan dengan pasien, pembimbing klinis yang diobservasi, dengan jelas memperkenalkan diri dan mahasiswa yang dibimbingnya kepada pasien. Harus dengan jelas diberitahukan kepada pasien bahwa tujuan dari sesi tersebut adalah sesi pembelajaran ${ }^{7}$ termasuk di dalamnya prosedur yang akan dilakukan kepadanya. Hal ini penting untuk menjaga kekooperatifan pasien dan minat pasien untuk berpartisipasi pada proses bedside teaching mendatang.

Dalam pelaksnaan bedside teaching, pasien harus selalu dijadikan pertimbangan utama sebagai subyek bukan obyek. Karena itu keselamatan, kenyamanan, dan kesediaan berpatisipasi harus selalu dipertimbangkan. Penelitian oleh $\mathrm{Nair}^{4}$ menemukan bahwa $77 \%$ pasien menikmati proses bedside teaching, dan $83 \%$ tidak mengalami ansietas saat proses tersebut berlangsung. Meskipun penelitian dilakukan di luar negeri dan mungkin berbeda konteks, proses pendidikan di Indonesia pun dapat diarahkan menuju pendidikan bedside teaching yang tetap megutamakan kenyamanan dan keamanan pasien

Pembelajaran di klinik dapat diterapkan pendekatan akronim BEDSIDE yang terdiri dari Briefing yang mencoba mencari tahu pengalaman dan pengetahuan mahasiswa sebelumnya, dan juga menjelaskan kepada pasien apa yang akan dilakukan mahasiswa. Expectation menjelaskan tentang hal apa yang diharapkan dipelajari mahasiswa dari bedside teaching tersebut. Demonstrasi bisa dilihat dalam dua konteks. Jika akan melakukan observasi, lakukan dengan melakukan interupsi seminimal mungkin. Pada bedside teaching yang diobservasi, interupsi dilakukan di saat yang tepat dan tidak terlalu berlebihan dan tidak mendominasi. Jika bedside teaching bersifat keterampilan yang harus dicontohkan, maka demonstrasi berupa peragaan oleh pembimbing klinik. Feedback spesifik harus diterapkan dengan menerapkan prinsip feedback konstruktif. Dalam proses ini juga harus dinklusikan Micro Skill Teaching. Kegiatan ini diakhiri dengan Debriefing dan Edukasi, tentang kesimpulan dan dari sumber mana mahasiswa dapat mempelajari lebih mendalam.

Pada bedside teaching yang diamati, tema yang akan dipelajari bersama telah jelas ditentukan. Tampak bahwa baik pembimbing klinik maupun mahasiswa sudah jelas dan paham tema apa yang akan mereka pelajari atau telaah hari itu. Meskipun dalam 
wawancara lanjutan tidak ditanyakan mengenai suatu panduan yang dibuat pembimbing klinik, namun diasumsikan telah terdapat panduan yang berasal dari fakultas. Sebuah panduan tentang apa yang akan diajarkan dalam bentuk suatu rancangan roadmap penting dimiliki. Hal ini dapat membantu mengurangi rasa keterkurangkendalian yang dapat timbul baik dari pertanyaan mahaiswa maupun dari pertanyaan pasien yang mungkin tidak selalu dapat dijawab dengan baik $^{7} \mathrm{Hal}$ ini bertolak belakang dengan proses kuliah dimana pemberi kuliah dapat memiliki kontrol yang lebih besar terhadap kejadian-kejadian yang akan terjadi. Hal ini dapat menurunkan tingkat kepercayaan diri pembimbing klinik. Adanya tujuan yang spesifik akan membantu pembimbing klinik lebih baik dalam memahami dan melaksanakan proses bedside teaching. Sebuah tema yang khusus seperti anamnesis, atau pemeriksaan fisik, atau follow up, atau edukasi dapat dipilih. Perlu dibedakan secara jelas pula apakah sesi bedside teaching bersangkutan merupakan proses observasi performa mahasiswa atau merupakan sebuah demonstrasi. Kegiatan juga harus dirancang sedemikian rupa sehingga melibatkan semua pihak. Agar mahasiswa dapat belajar secara maksimal, maka harus dipilih pasien yang baik. Pasien baik bisa ditinjau dari segi kasus yang merupakan kompetensi yang dituntut dari seorang dokter umum sampai level tertentu. Selain itu pasien yang baik juga harus memiliki karakteristik temuan yang baik yang dapat dipelajari dan menambahkan rangkaian pengetahuan dan mampu membantu mahasiswa untuk mengintegrasikan pengetahuan yang telah diperoleh dengan pengetahuan barunya. Selain itu jika memungkinkan pasien dapat memberikan masukan dari sisi pasien tentang bagaimana mahasiswa tersebut secara professional memperlakukan pasiennya. Dalam melaksanakan bedisde teaching, aspek pelayanan terhadap pasien juga harus tetap selalu diutamakan. Karena itu pembimbing klinik harus memiliki komitmen waktu yang baik, agar dalam proses pembelajaran tersebut, tidak terlalu lama dan mengganggu kenyamanan pasien.

\section{Pada suatu bedside teaching,} terdapat serangkaian ground rules yang harus disosialisasikan ${ }^{7}$ Pembimbing klinik juga harus memperkenalkan prinsip-prinsip dasar baik yang bersifat praktis maupun yang bersifat filosofis. Hal praktis termasuk kedisiplinan, ketepatan waktu, cara berpakaian, kerahasian data pasien. Aspek filosofi seperti menghormati pasien, kolega, kerahasiaan, consent, dan keterbukaan terhadap pendapat orang lain. Prinsip ini biasanya hanya dijelaskan pada fase awal sehingga harus dipastiakn hal tersebut dipahami dan dapat dilaksankansesuai kespakatan. Hal ini tidak tampak pada bedside teaching yang diobservasi. Hal ini dapat dipahami sebab sesi yang diamati adlah sesi assessment. Tentunya pada sesi bedside teaching sebelumnya, mahasiswa sudah berulang kali dijelaskan, dan 
dipraktekan tentang berbagai prinsip yang wajib diterapkan dalam suatu proses bedside teaching.

Pembimbing klinis yang diobservasi memiliki kepekaan yang tinggi terhadap halhal penting dan sensitif. Pembimbing mampu mengidentifikasikan hal hal krusial yang perlu dilakukan mahasiswa, namun saat mahasiswa tidak melakukannya; pembimbing klinis tidak serta merta memarahi atau mengkoreksi secara punitive kepada mahasiswa di depan pasien. Dalam diskusi pasca bedside teaching, pembimbing klinis menjelaskan bahwa prinsip pembelajaran bedside yang baik bila terjadi kesalahan adalah bahwa pasien tidak perlu mengetahui keslahan apa yang telah terjadi. Pada mahasiswa yang diamati, terdapat serangkaian kesalahan, baik kesalahan mayor maupun kesalahan minor. Diamati bahwa beberapa kesalahan minor seperti tehnik pemeriksaan auskultasi paru yang kurang tepat. Diamati bahwa pembimbing klinik dengan tetap tidak menginterupsi jalannya proses pemeriksaan, membantu memberikan input kepada mahasiswa tentang kesalahan yang telah dilakukan dengan cara membantu memposisikan stetoskop dengan benar. Hal ini tetap dilakukan tanpa sepengetahuan pasien sehingga pasien tetap merasa nyaman dan mahasiswa tidak secara frontal dipermalukan di depan pasien. Penciptaan kondisi belajar seperti ini sangat baik dan memberikan manfaat yang besar kepada mahasiswa.
Dalam bedside teaching yang diobservasi mahasiswa langsung memeriksa di ruang rawat pasien. Proses ini akan lebih baik jika dilakukan di suatu ruang yang terpisah ${ }^{6}$ Meskipun hal ini ideal namun menimbang segi kepraktisan dan ketersediaan ruang yang ada, maka pemeriksaan dilaksanakan langsung di ruang pasien. Hal ini dapat disikapi dengan tidak terlalu banyak mendiskusikan hal-hal yang berhubungan dengan materi pembelajaran di depan pasien.

Seorang pembimbing klinik harus memformulasikan pertanyaan dengan tepat. Dalam observasi didapati bahwa pertanyaan terbuka digunakan pada fase awal. Pertanyaan berupa pertanyaan terbuka. Pertanyaan terbuka lebih baik diguanakan pada fase awal dibandingkan dengan pertanyaan tertutup ${ }^{6}$.Selanjunya beberapa pertanyaan tertutup dapat digunakan untuk menganalisa lebih lanjut. Pertanyaaan yang murni recall hendaknya dihindari. Pertanyaan diformulasikan sedemikain rupa menyesuaikan dengan pengetahuan yang sudah ada, namun membangun pola pikir yang lebih tinggi atau kompleks.

Pada diskusi setelah bertemu dengan pasien, pembimbing kurang memberi kesempatan kepada mahasiswa untuk mengeksplorasi tentang proses yang dilalui. Idealnya seorang mahasiswa menceritakan apa yang telah dilakukannya dengan baik dan apa yang kurang dan strategi apa yang direncanakan untuk memperbaiki hal tersebut ${ }^{6}$. Pembimbing klinik memintas 
langkah ini dan langsung masuk pada hasil observasinya. Namun demikian hasil onservasi telah dibuat spesifik dan pembimbing klinik juga menyarankan langkah perbaikan. Penulis menganilsa hal ini dilakukan karena keterbatasan waktu pembimbing klinik.

Bebrapa hal penting dalam diskusi setelah bertemu dengan pasien harus dipertimbangkan. Pembimbing klinik harus cermat memilih pertanyaan sehingga tidak mengajukan pertanyaan yang bersifat sangat terbuka yang membuat mahasiswa bingung mengarahkan kearah mana pertanyaan tersebut hendak dijawab. Jika dalam menjawab mahasiswa melakukan kesalahan, pembimbing klinik melakukan koreksi dengan efektif tanpa perlu memarahi dan menjatuhkan mental mahasiswa. Dalam pembelajaran yang terdiri dari beberapa mahasiswa, pembimbing klinik hendaknya menghindari terjebak dalam diskusi dengan mahasiswa yang dominan, atau memberikan kesempatan untuk mempraktekan serangkaian prosedur hanya kepada satu orang mahasiswa saja. Pembimbing klinik memastikan bahwa diskusi ebrjalan dengan efektif, dan menghindari diskusi panjang bertele-tele tanpa point penting yang jelas. Dalam diskusi seseorang pembimbing klinik harus mau mengakui jika yang bersangkutan tidak dapat menjawab atau menjelaskan suatu tema tertentu. Hal ini akan menjadi contoh yang baik kepada para mahasiswa untuk mampu mengenali batas kemampuan sehingga mendorong mahasiswa untuk bertanya tentang hal-hal yang tidak diketahui. Namun harus dipastikan bahwa hal ini terjadi diluar kontak dengan pasien, sehingga mahasiswa dapat dengan leluasa bertanya, emgkonfirmasikan pengetahuan mereka, dan memperjelas hal-hal yang masih membingungkan ${ }^{7}$.Pembimbing klinik juga harus menyatakan kesediaan mereka untuk belajar dari mahadiswa dan dari pasien. Akan sangat tidak baik jika sesorang mahasiswa senior tidak mampu menjawab suatu pertanyaan kemudian pertanyaan tersebut dilemparkan kepada mahasiswa yang lebih yunior. Memastikan bahwa seluruh baik mahasiswa maupun residen terlibat dalam sesi bedside teaching tersebut penting dilakukan. Menyadari begitu banyaknya prosedur yang harus dilakukan sementar waktu yang dimiliki terbatas, pembimbing klinik haruslah selektif memilih prosedur mana saja yang penting dan hanya dapat dilakukan dalam kegiatan bedside.

Dari hasil observasi, didapati bahwa feedback yang diberikan oleh pembimbing klinik adalah feedback yang didasari pengamatan. Feedback diberikan tepat waktu, praktis, dan membangun. Kondisi satu dan satu memungkinkan feedback menjadi lebih spesifik dan dapat mencakup hal-hal yang sensitif. Dalam observasi yang dilakukan pembimbing memberikan masukan tentang mahasiswa yang tampak nervous. Hal ini cukup sensitif dan akan kurang tepat disampaikan di forum yang besar, namun pada bedside teaching, hal ini dapat didiskusikan dengan baik. Proses yang 
dilakukan penting karena mahasiswa sangat membutuhkan umpan balik $^{6}$. Sebagai pembimbing klinik, dari observasi yang dilakukan, yang bersangkutan telah melakukan fungsi observasi dengan baik tanpa terlalu banyak intervensi berlebihan. Dengan observasi yang baik dapat dinilai kemampuan berkomunikasi, anamnesis, pemeriksaan fisik, kemampuan memecahkan masalah, tingkah laku dan pengetahuan dapat dinilai dengan melakukan pengamatan yang baik ${ }^{7}$. Lewat pengamatan ini dapat disimpulkan suatu masukan yang bermakna bagi mahasiswa baik berupa nilai maupun saran-saran untuk perbaikan.

Dalam suatu rumah sakit pendidikan seorang pasien dapat saja bertemu dengan berbagai dokter. Terkadang pasien mengalami kebingungan tentang siapa yang sebenarnya bertangung jawab terhadap penanganan penyakitnya ${ }^{7}$. Pembimbing klinik yang diobservasi dengan sangat baik melakukan hal ini. Selain memperkenalkan dirinya dan mahasiswa yang akan melakukan pemeriksaan, pembimbing klinik juga menjelaskan dan menanyakan pertanyaan konfirmatif kepada pasien mengenai dokter penanggung jawab yang menangani dirinya. Hal ini pun tampak pada akhir bedside teaching, pembimbing klinik yang diobservasi kembali menjelaskan bahwa penanganan terhadapnya akan dilakukan oleh dokter penanggung jawab. Hal ini penting diberitahukan kepada pasien, untuk menegaskan bahwa proses bedside teaching yang dialaminya, tidak akan mempengaruhi pelayanan medis yang diberikan kepadanya. Hal ini bermanfaat untuk menjaga kredibilitas institusi rumah sakit serta tingkat partisipasi pasien terhadap proses Bedside teaching. Sebelum proses bedside teaching berlangsung, pasien juga memperoleh penjelasan yang cukup tentang apa yang akan terjadi, termasuk di dalamnya prosedur yang akan dilakukan kepadanya.

Selama observasi, peran role model adalah fungsi yang dijalankan dengan sangat baik oleh pembimbing klinik. Sebagai seorang klinisi yang cukup senior, pembimbing klinik bersangkutan telah sangat baik menjadi contoh bagi para juniornya. Pasien akan merasa senang jika mereka dilibatkan dalam proses pengajaran, merasa dibutuhkkan, dan diperkenankan untuk mengajukan pertanyaan berkaitan dengan penyakit mereka. Kondisi ini menjadi kesempatan bagi pembimbing klinik untuk mencobtohkan professionalism dalam interaksi dan pelyanan kepada pasien, tidak hanya dalam bentuk teori, melainkan langsung dalam bentuk praktek nyata ${ }^{7}$. Pembimbing klinik senantiasa menjaga interaksi yang hangat dengan pasien bedside teaching Selain memberikan role-model yang baik dalam proses bedside teaching, pembimbing klinik yang diobservasi juga menjalankan peran yang sangat baik dalam peningkatan kualitas pelayanan medis di rumah sakit. Hal penting yang berhasil diobservasi adalah kepedulian pembimbing klinik bersangkutan terhadapa usaha pengendalian infeksi di rumah sakit. 
Pembimbing klinis tersebut menaruh perhatian besar terhadap pentingnya prosedur cuci tangan yang baik, serta kebiasaan yang harus dihindari untuk mengurangi tingkat infeksi di rumah sakit. Diamati, pembimbing klinik sesusai memeriksa pasien, bersama dengan mahasiswa yang dibimbingnya melakukan proses cuci tangan yang benar. Hal ini dilakukan tidak terbatas kepada residen atau dokter muda saja, melainkan juga kepada tim pelayanan di rumah sakit secara keseluruhan termasuk perawat dan mahaiswa perawat. Dalam insiden yang diamati pembimbing klinik tersebut dengan jeli mengamati soerang siswa perawat yang nmelakukan prosedur cuci tangan dengan kurang tepat serta mengenakan cincin. Pemberian feedback dilakukan dengan cara yang halus tanpa memarahi serta mengajak siswa perawat bersangkutan untuk berdiskusi mengenai hal tersebut.

Dalam bedside teaching kesimpulan adalah komponen yang penting diberikan baik kepada mahasiswa maupun kepada pasien. Pembimbing klinik dapat menjelaskan kepada pasien hal-hal dalam bedside teaching yang telah berlangsung manakah yang aplikatif uintuk dirinya, dan juga dapat dilakukan edukasi isngkat kepada pasien tentang penyakitnya.

Pada fase akhir haruslah dialokasikan waktu sesi umpan balik terhadap proses bedside teaching itu sendiri. Dalam observasi yang dilakukan, mahasiswa dan pembimbing klinik mengalokasikan waktu 5 menit untuk melakukan refleksi tentang proses yang telah berlangsung. Sesi dibuat singkat dan jelas dan mendiskusikan hal-hal penting yang telah berjalan baik dan yang belum berjalan dengan baik. Hal ini bermanfaat bagi pelaksanaan bedside teaching selanjutnya, meningkatkan moralitas mahasiswa, dan memberikan kesempatan bagi mahaiswa untuk mengekspresikan kekurangan dan kefrustrasian mereka, serta memberikan masukan bagi pelayanan medis itu sendiri ${ }^{7}$. Dalam proses feedback yang berlangsung, terdapat beberapa kekurangan yang diamati. Dalam proses tersebut, residen sebagai penanggung jawab pasien, karena kendala waktu dan tuntutan pelayanan, tidak dapat turut serta dalam diskusi. Hal ini penting karena dokter penanggung jawab tentunya lebih sering berkontak dengan mahasiswa bersangkutan dan lebih mampu memantau perkembangan mahasiswa tersebut sehingga masukan mereka sangatlah bermanfaat. Selain itu, meskipun tampak bahwa pembimbing klinik telah sangat berusaha terbuka dan bersikap netral terhadap mahasiswa. Masih diamati bahwa mahasiswa merasa enggan untuk mengkritisi jalannya proses bedside teaching. Belum dapat ditelusuri lebih lanjut apakah hal-hal baik yang dikemukan memang sesuai dengan fakta yang ada ataukah hal tersebut terungkap karena rasa segan terhadap pembimbing klinik. Menanggapi hal ini disrankan bahwa input bagi proses bedside teaching itu sendiri juga diperlengkapi dengan mekanisme yang memungkinkan 
mahasiswa memasukan usulan tanpa kehadiran pembimbing klinis bersangkutan. Adanya kotak saran dapat menjadi alternatif. Adanya masukan ini akan sangat bermanfaat bagi perkembangan sesi bedside teaching selanjutnya. Sama halnya dengan proses persiapan pada sesi yang telah berlalu, masukan dari sesi yang telah berlalu dapat bermanfaat untuk meningkatkan kemampuan pembimbing, meningkatkan kualitas proses bedside teaching, dan menjadikan bedside teaching wahana pembelajaran yang menyenangkan bagi mahasiswa dan pembimbing klinik ${ }^{7}$.

Janicik dan Fletcher $^{1}$ menemukan dalam studinya beberapa faktor yang dianggap membuat seorang klinisi enggan untuk melakukan bedside teaching diantaranya: mengkhawatirkan ketidaknyamanan pasien, kerahasiaan yang kurang, pasien yang sulit dicari, minat mahasiswa yang kurang terhadap bedside teaching, menyita waktu. Selain itu didentfikasikan juga beberapa keuntungan dari proses bedside teaching diantaranya, peoses yang dapat memberikan kesempatan intraksi dengan pasien, mengobservasi kemampuan mahasiswa dan memberikan contoh sebagai role model, terdapat proses humanism yang melibatkan pasien, memberikan kesempatan kepada mahasiswa untuk mempraktekan bertutur kata yang baik, penerapan belajar aktif yang merupakan karakteristik pembelajaan dewasa dan juga meningkatkan pengetahuan pasien tentang penyakit yang diderita.
Terdapat berbagai karakteristik yang merupakan suatu bedside teaching yang ideal $^{1}$. Hal tersebut terdiri dai tiga domain utama yaitu komponen kenyamanan pasien, pengajaran yang terfokus, serta dinamika. Komponen kenyamanan pasien terdiri dari menanyakan kesedian untuk keterlibatan, menjelaskan dokter penanggung jawab, emnghindari penggunaan bahasa yang tidak dimengerti oleh pasien, serta mampu memberikan semangat kepada pasien. Meskipun proses permintaan kesediaan tidak dapat diobservasi, observer yakin bahwa hal tersebut telah dilakukan sebelumnya oleh residen yang bertanggung jawab pada proses ujian tersebut. Pembimbing klinik juga secara singkat dalam pendahuluannya meinta kesediaan pasien untuk terlibat. Komponen pengajaran yang terfokus mempertimbangkan penerapan aspek microskill teaching dalam bedside, pengjaran terstruktur dengan tujuan yang jelas, mengajarkan prinsip, memberikan umpan balik, serta penerapan role model sebagai klinisi. Komponen terakhir adalah dinamika kelompok yang mencakup kesepakatan waktu dan keterlibatan anggota. Komponen terakhir ini kurang dapat diamati dari sesi yang diobservasi karena observasi dilakukan pada konteks ujian.

Keungulan dari proses bedside teaching adalah karakter observasionalnya. Bedside teaching dapat menyediakan observasi tingkah laku mahasiswa oleh pembimbing klinik, ataupun sebaliknya ${ }^{6}$. Bebagai reaksi dalam hubungan seorang 
klinisi dengan pasien, atau bahkan reaksi saat berada dalam tekanan. Jia seorang pembimbing klinik dapat membangun relasi yang baik dengan mahasiswanya, maka ia dapat mendiskusikan pendapat tingkah laku professional yang akan lebih sulit dilaksanakan di kelompok besar.

Keuntungan lain dari proses belajar bedside teaching adalah mampu disesuaikan dengan kebutuhan belajar mahasiswa ${ }^{6}$. Ausbel $^{6}$ menyatakan bahwa proses pembelajaran harus didasari dengan apa yang mahasiswa telah ketahui. Pada kelas besar,seminar, tutorial, akan sulit untuk mengidentifikasikan dan merespon terhadap berbagai tingkat pengetahuan yang dimiliki mahasiswa, namun pada pengajaran satu dengan satu maka materi dapat disesuaikan dengan prior knowledge mahasiswa.

Bedside teaching dapat dibandingkan keunggulannya dengan berbagai metode pengajaran lain dalam setting klinik ditinjau dari berbagai aspek: ${ }^{6}$

Tabel. 1 Komparasi metode pengajaran pada setting klinik

\begin{tabular}{|c|c|c|c|c|c|}
\hline & Kuliah & Seminar & $\begin{array}{l}\text { Diskus } \\
\text { i PBL }\end{array}$ & $\begin{array}{l}\text { Tutoria } \\
\text { I klinik }\end{array}$ & $\begin{array}{l}\text { One- } \\
\text { to-one } \\
\text { clinical } \\
\text { attach } \\
\text { ment }\end{array}$ \\
\hline Efektifitas & Tinggi & Sedang & Rendah & Rendah & $\begin{array}{l}\text { Sangat } \\
\text { rendah }\end{array}$ \\
\hline $\begin{array}{l}\text { Pembelajar } \\
\text { an aktif }\end{array}$ & Rendah & Bervariasi & Tinggi & $\begin{array}{l}\text { Sedang } \\
\text {-tinggi }\end{array}$ & $\begin{array}{l}\text { Sangat } \\
\text { tinggi }\end{array}$ \\
\hline $\begin{array}{l}\text { Umpan } \\
\text { Balik }\end{array}$ & Rendah & Sedang & Tinggi & $\begin{array}{l}\text { Sedang } \\
\text {-tinggi }\end{array}$ & $\begin{array}{l}\text { Sangat } \\
\text { tinggi }\end{array}$ \\
\hline $\begin{array}{l}\text { Role model } \\
\text { dalam } \\
\text { setting } \\
\text { klinik }\end{array}$ & Rendah & Rendah & Sedang & Tinggi & $\begin{array}{l}\text { Sangat } \\
\text { tinggi }\end{array}$ \\
\hline
\end{tabular}

Proses Bedside teaching adalah proses yang bersifat multimodal yang memadukan interaksi visual, verbal, dan taktil dengan pasien ${ }^{4}$. Beberapa proses Bedside Teaching telah ditelantarkan dan dilaksanakan seadanya yang berakibat pada berkurangnya keterampian klinis mahasiswa lulusan. Mengingat pentingnya proses ini bagi mahasiswa maka selruh pihak yang terlibat baik institusi, pembimbing klinik, mahasiswa, dan pasien harus memahami dan menjalankan perannya dengan baik dalm proses bedside teaching.

\section{Kesimpulan}

Bedside teaching adalah suatu kondisi yang baik untuk sebuah interaksi yang relatif spontan antara mahasiswa, pembimbing klinik, dan pasien. Dalam sesi Bedside Teaching terdapat kemungkinan terjadi prosedur yang benar ataupun yang kurang tepat. Disnilah pentingnya kejelian seseorang pembimbing klinik untuk mengamati dan member masukan sehingga dapat menjadi suatu bedside teaching yang efektif. Selain itu banyak hal yang kurang dapat diajarkan dalam setting kelas membuat bedside teaching semakin penting. Proses refleksi juga harus diterapkan pada setiap aspek bedside teaching sehingga meningkatkan kemampuan pembimbing klinik, meningkatkan kualitas bedside teaching yang pada akhirnya menjadi wahana pembelajaran yang efektif dan efisien bagi mahasiswa. 


\section{DAFTAR PUSTAKA}

1. Janicik,RW; Fletcher, KW. 2003. Teaching at bedside, a new model. Medical Teacher; 25;2:127-130

2.Gonzalo et. al., 2009. Attending round and bedside case presentation: medical student and medicine resident experience and attittude; $21 ; 2: 105-110$

3. Gonzalo et. al., 2014. Content and timing of feedback and reflection: a multi-center qualitative study of experienced bedside teachers. British Medical Journal; 14: 212

4. Ahmed, MK. 2002. What happened to bedside clinical teaching. Medical Education; 36: 1185-1188

5. Cox, E. 2005. Adult learners learning from experience using a reflective practice model to support workbased learning. Reflective practice; 6; 4: 459-472

6. Gordon, J. ABC of learning and teaching in medicine:one to one teaching and feedback. British Medical Journal; 326: 543-545

7. Ramani,S. 2003. Twelve tips to improve bedside teaching. Medical Teachers; 25; 2:112-115

8. Spencer J. ABC of leraning and teavhing in medicine:Learning and teaching in clinical environment.2003. British Med Journ;326, pp 590-4

9. Mc Allister L et.al. Facilitating Learning in Clinical Setting.1997. United Kingdom,Nelson Throne. pp 3-4 